Chicago-Kent College of Law

Scholarly Commons @ IIT Chicago-Kent College of Law

All Faculty Scholarship

Faculty Scholarship

February 2007

\title{
Toward a New Economic Constitution: Judicial Disciplines on Trade Politics
}

Sungjoon Cho

IIT Chicago-Kent College of Law, scho1@kentlaw.iit.edu

Follow this and additional works at: https://scholarship.kentlaw.iit.edu/fac_schol

Part of the American Politics Commons, International Relations Commons, and the International Trade Law Commons

\section{Recommended Citation}

Sungjoon Cho, Toward a New Economic Constitution: Judicial Disciplines on Trade Politics, 42 Wake Forest L. Rev. 167 (2007).

Available at: https://scholarship.kentlaw.iit.edu/fac_schol/183

This Article is brought to you for free and open access by the Faculty Scholarship at Scholarly Commons @ IIT Chicago-Kent College of Law. It has been accepted for inclusion in All Faculty Scholarship by an authorized administrator of Scholarly Commons @ IIT Chicago-Kent College of Law. For more information, please contact jwenger@kentlaw.iit.edu, ebarney@kentlaw.iit.edu. 
Article Submission

\section{Toward a New Economic Constitution: Judicial Disciplines on Trade Politics}

By Sungjoon Cho

Assistant Professor of Law Chicago-Kent College of Law, Illinois Institute of Technology 565 West Adams St. Chicago, IL 60201 (312) 906-5169 scho1@kentlaw.edu 


\section{Toward a New Economic Constitution: \\ Judicial Disciplines on Trade Politics}

\section{Table of Contents}

I. Introduction: Protectionism as an Icon of Trade Politics ............................................. 2

II. Understanding Protectionist Trade Politics: Structure, Context and Psychology ......... 7

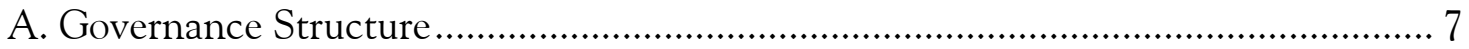

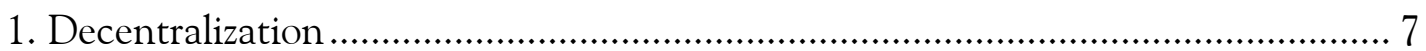

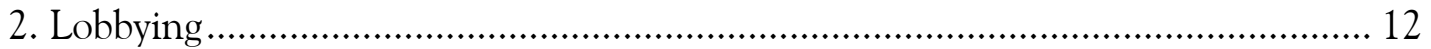

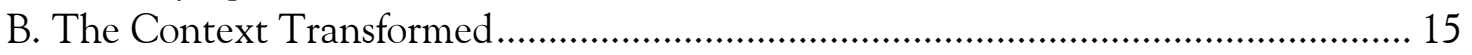

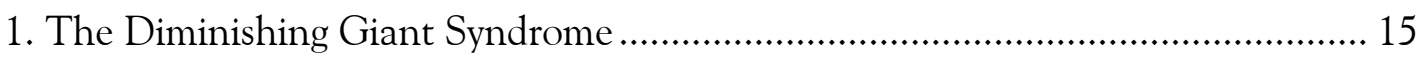

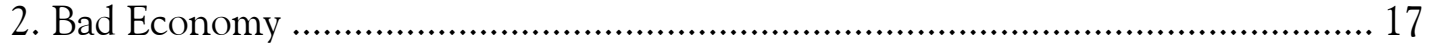

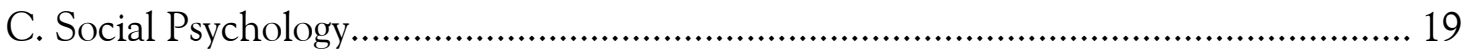

1. Asymmetrical Perception of Gains and Pains of Trade......................................... 20

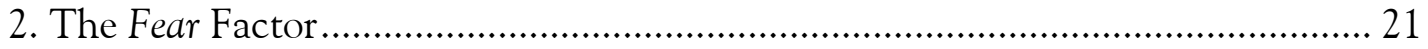

III. Revealing Pathologies of Protectionist Politics: A Dual Crisis.................................... 23

A. Domestic Crisis: Constitutional Failure ................................................................. 23

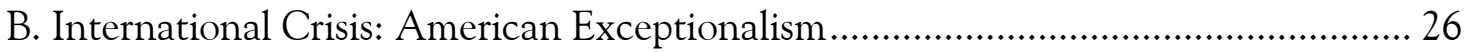

IV. Judicial Regulation of Protectionist Politics: A New Constitutional Dynamics ......... 27

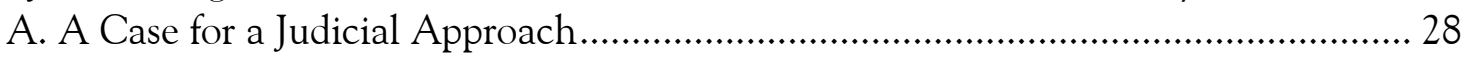

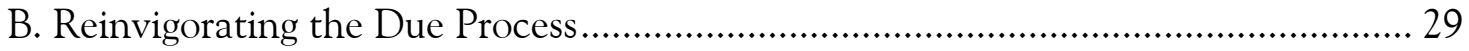

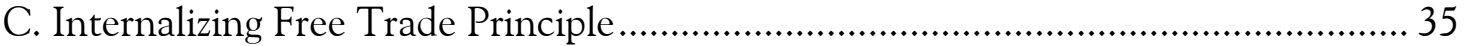

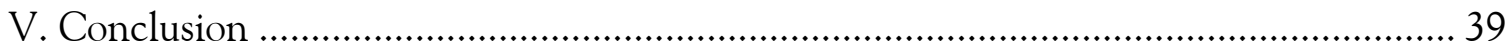




\section{Introduction: Protectionism as an Icon of Trade Politics}

A paroxysm of the United States' protectionist drive has recently shocked the world. To protect domestic steel industries from foreign competition, the Bush administration launched the so-called "Steel Initiative," ${ }^{1}$ soon after it took office in 2001. ${ }^{2}$ Under the initiative, the federal government could impose additional tariffs on foreign steels in the name of safeguard measures. ${ }^{3}$ The federal government also protected the interests of agricultural industries in farm states such as Texas and Mississippi ${ }^{4}$ by introducing the "Farm Security and Rural Investment Act of 2002" or "Farm Bill" in which the Congress committed lavish farm subsidies of up to 180 billion dollars for several years. ${ }^{5}$ Even President Bush himself described this bill as "generous." ${ }^{6}$ The United States' farm support in 2004, hovering around forty-six billion dollars, marked an increase of eighteen per cent, which is the largest among the world's rich countries. ${ }^{7}$ Not surprisingly, national politics, particularly as evinced by the 2000 and 2004 elections and heated "swing state" battles, ${ }^{8}$ lay behind this surge of protectionist campaigns.

\footnotetext{
${ }^{1}$ The White House, Statement by the President Regarding a Multilateral Initiative on Steel (Press Release, Jun. 5, 2001), available at http://www.whitehouse.gov/news/releases/2001/06/20010605-4.html (last visited on May 14, 2003) [hereinafter White House Press Release].

${ }^{2}$ See Daniel T. Griswold, A Wall of Steel, available at http://www.freetrade.org/pubs/articles/dg-7-801.html (last visited on Aug. 10, 2005).

${ }^{3}$ White House Press Release, supra note _.

${ }^{4}$ The White House, President Signs Farm Bill (Press Release, May 13, 2002), available at http://www.whitehouse.gov/news/releases/2002/05/20020513-2.html (last visited on May 14, 2003) [hereinafter Farm Bill].

${ }^{5}$ See Houses Pass $\$ 180$ B Farm Bill, The Associated Press, May 2, 2002.

${ }^{6}$ Farm Bill, supra note.

${ }^{7}$ Raphael Minder et al., OECD Study Shows Scant Reduction in Subsidies to Farmers over Past 10 Years, Fin. TIMES, Jun. 22, 2005, at 1.

${ }^{8}$ See Virginia Postrel, Why Bush Stiffed Enron, WALl St. J., Jan. 25, 2002, at A18.
} 
Protectionist trade politics has become even more tenacious and atmospheric than ever before. This spring, the U.S. Secretary of Energy suggested lifting tariffs on ethanol to meet rising domestic demand for this alternative energy source. Because the U.S. government commits billions of dollars in subsidies to producers of domestic corn-based ethanol, importing cheaper Brazilian sugar-based ethanol by lifting a fifty-four-cent-agallon tariff on foreign ethanol sounds compelling. Yet, this proposal infuriated politicians whose constituencies produce domestic ethanol, including Senator Charles Grassley from Iowa, who lambasted the proposal as a "kick in the teeth for rural America." The formidable corn lobby from the Farm Belt eventually torpedoed this proposal in the House. $^{10}$

Understandably but unjustifiably, the upcoming November mid-term election this year has provided protectionism with fresh momentum, though protectionist issues are often cloaked as security concerns or other popular nationalistic themes. For example, the Congress has recently aborted Dubai Port World's takeover of a U.S. port and bashed China over its record-high bilateral trade deficit with the U.S. ${ }^{11}$ Many politicians seemingly assume that the U.S. commitment to open trade will militate against national security, ${ }^{12}$ despite the high risk of this position being abused as pretexts for sheer

\footnotetext{
${ }^{9}$ See Alan Beattie, Brake on Biofuels as Obstacles Clog the Road, FIN. TimES, May 9, 2006, at 6.

${ }^{10}$ End Ethanol Subsidies Now, L.A. TIMES, May 22, 2006; Corn Laws of the $21^{\text {st }}$ Century, N.Y. TIMES, May 22, 2006.

${ }^{11}$ See Doha in the Doldrums, Fin. TIMES, Apr. 06, 2006, at 12.

${ }^{12}$ See The Rising Tide of U.S. Protectionism, Fin. Times, Mar. 13, 2006, at 12.
} 
protectionism. ${ }^{13}$ In a similar vein, Bill Thomas, Chairman of the House Ways and Means

Committee, admitted that protectionism against the backdrop of a nationalistic stance ("preserving our way of life") has become a trendy campaign theme. ${ }^{14}$

Perhaps protectionism is inevitable in a representative democracy. ${ }^{15}$ "All politics is local, ${ }^{16}$ and every industry has its First Amendment right to lobby and petition to preserve its special interest. Protectionism may be the price we pay for democracy. Nevertheless, the current wave of protectionism in the United States is troubling in its frequency and scale. It certainly looms larger than seasonal election year politics. ${ }^{17}$ The U.S. protectionist politics has also complicated the current Doha round negotiations under the World Trade Organization (WTO) ${ }^{18}$ because the Unites States refused to substantially reduce trade-distorting farm subsidies. ${ }^{19}$ Yet, protectionism is only likely to deepen as the U.S. economy adjusts itself to a new economic environment which imposes

${ }^{13}$ Gray G. Yerkey, U.S. Trade Official Cites 'Worrisome' Trend Toward Protectionism Tied to Security Fears, 23 INT'L TRADE ReP., Mar. 30, 2006, at 506.

${ }^{14} \mathrm{Id}$.

${ }^{15}$ Public choice theorists proffer a gloomy conclusion that politics in the machine of democracy tends to eventuate protectionism on account of rent-seeking behaviors of interest groups (domestic producers). ChARLES K. ROWley ET AL., TRADE PROTECTION IN THE UNITED STATES 20 (1995).

${ }^{16}$ See generally Tip O'Neill, All POLITICS IS LOCAL, AND OTHER RULES OF THE GAME (1994). ${ }^{17}$ In this context, the World Trade Organization (WTO) has officially warned that the U.S. should curb protectionism. Daniel Pruzin, WTO Review Urges U.S. to Head Off Protectionism; China Criticizes Port Reaction, 23 Int'l Trade Rep. Mar. 23, 2006, at 437; Doug Cameron \& Frances Williams, WTO Calls on U.S. to Resist Protectionism, Mar. 23, 2006.

${ }^{18}$ Marrakech Agreement Establishing the World Trade Organization, April 15, 1994, Final Act Embodying the Results of the Uruguay Round of Multilateral Trade Negotiations [hereinafter WTO Agreement], Legal InstRumeNTS-RESUlTS OF THE URUGUAy ROUND, 6, 6-18; 33 I.L.M. 1140, 1144-1153 (1994).

${ }^{19}$ Doha Round Suspended Indefinitely After G-6 Talks Collapse, BRIDGES WeEKLY TRADE NEWS DigEST - Vol. 10, Number 27, 26 July 2006. Some politicians, in particular from the farm states, even float the idea of extending, not modifying, the internationally contentious Farm Bill. About That Free Trade, N.Y. TiMES, May 15, 2006. 
more severe global competition than ever before. Today, politicians regularly face the temptation to respond to economic woes with protectionism. ${ }^{20}$

Against this backdrop, this article problematizes protectionism, which is iconic of trade politics, and suggests certain legal means to discipline it. This article argues that law should no longer be subordinated to the politics of capture but instead offer a prescription to trade politics so as to fulfill such constitutional goals as economic freedom and deliberative democracy. Therefore, this article is oriented to legal regulation of trade politics, not political regulation of trade law.

In an attempt to better comprehend trade politics, Part II analyzes the phenomenon of protectionism through three lenses: government structure, context and social psychology. It concludes that protectionism is attributable to, and also reinforced by, the United States' decentralized government structure, altered econo-political circumstances, and cognitive problems in perceiving gains and pains from trade.

Part III then describes the various costs of protectionist trade politics. Protectionism sneakily imposes a huge protectionist tax on consumers and consuming industries for everyday items such as bras, shirts, shrimp, sugar, lumbers, and even

\footnotetext{
${ }^{20}$ See Martin Feldstein, The Return of Saving, 85 FOREIGN AFF. 87, $92-93$ (2006) (warning that a failure of economic adjustment by both the U.S. and its trading partners in the era of a higher U.S. savings rate will precipitate a surge of protectionism globally); Brian Reading, Woe Betides Us (and the U.S.) If Depreciation of Dollar Fails in a World of Excess Supply, Fin. TimES, May 31, 2006, at 10.
} 
candles. ${ }^{21}$ It also deviates from global trading norms, which the U.S. hypocritically continues to preach adherence to for the rest of the world. This double standard creates images of "American Exceptionalism"22 and undermines the effectiveness of the multilateral trading system. For example, the recent extravagant U.S. farm subsidies made a "mockery of the idea that the Doha round is to be a development round."23

Confronting these ever-intensifying pathologies of protectionism borne by trade politics, Part IV suggests certain judicial options to discipline trade politics and thus curb the current wave of protectionism within the constitutional framework. It argues that the Court should reinvigorate both structural and substantive due process to monitor and check atrophying protectionist policies. Legislative process should become more disciplined and transparent to prevent procedural abuses, like "riders." Measures suspected as protection should undergo strict scrutiny, and should fail absent compelling justifications for them. Part IV also submits that certain essential global trading norms, such as the non-discrimination principle, may be internalized by the Court under constitutional doctrines, such as Charming Betsy. These constitutional options encompass both a Madisonian ideal (protecting broad public interests against narrow special interests) and a Lockeian ideal (upholding economic freedom), while they also serve the WTO's ideal (free trade).

${ }^{21}$ According to one estimate, such a protection tax is equivalent to a national sales tax of 6 percent. See Consumers for World Trade, Protectionism in America: Watch Your Wallet!, available at http://www.cwt.org/ (last visited on Jan. 20, 2006).

${ }^{22}$ Harold Hongju Koh, On American Exceptionalism, 55 STAN. L. REV. 1479, 1483.

${ }^{23}$ World Trade: Coming Unstuck, THE ECONOMIST, at 14, Nov. 2, 2002; The Zoellick Plan: Trading Insults, THE ECONOMIST, at 67, Nov. 30, 2002. 


\title{
II. Understanding Protectionist Trade Politics: Structure, Context and Psychology
}

\author{
A. Governance Structure
}

\section{Decentralization}

Under Article II of the U.S. Constitution, foreign affairs power belongs to the president. ${ }^{24}$ However, the president cannot claim a monopoly in foreign policy-making since in practice the power is shared by Congress. ${ }^{25}$ The separation of powers in the area of foreign policy has been a puzzle to many observers. Alex de Tocqueville believed that U.S. foreign policy lacked "patience, persistence and secrecy." 26 This observation, which is a testimonial to the "decentralized" structure of the U.S. government, has frequently been reiterated by subsequent scholars. ${ }^{27}$ Being one aspect of foreign policy, ${ }^{28}$ trade policy

${ }^{24}$ U.S. CONST. art. II, §2. See also Saikrishna B. Prakash \& Michael D. Ramsey, The Exectuive Power over Foreign Affairs, 111 YALE L. J. 231 (2001).

${ }^{25}$ This decentralization or rigorous "separation of powers" is a common feature which is derived from the Constitution and affects most US foreign policies. Louis Henkin observed that:

"Perhaps the 'contraption' was doomed to troubles from the beginning, for although the Framers ended the chaos of diplomacy by Congress and of state adventurism, the web of authority they created, from fear of too much government and the need for contemporary political compromise, virtually elevated inefficiency and controversy to the plane of principle, especially in foreign relations."

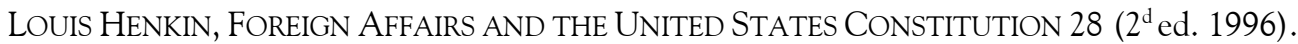

${ }^{26}$ See notably ROBERT L. PAARLBERG, LEADERSHIP ABROAD BEGINS AT HOME: U.S. FOREIGN

ECONOMic Policy AFTer THE COld WAR 32 (1995) (citing AleXIS DE TOCQUEVILle, DeMOCRACY IN AMERICA 243-44 (1945)).

${ }^{27}$ Stanley Hoffman viewed the U.S. government structure as "too complex and too sprawling" to produce coherent yet flexible foreign policies. Id., n. 2 (citing Stanley Hoffman, Gulliver's Troubles, Or the Setting of American Foreign Policy (1968)). Likewise, Paarlberg eloquently presented a list of seven "enduring and distinctive" features of the U.S. political system that have undermined its external leadership: "divided government," "congressional power over trade," "disunity and discontinuity in the 
exhibits the same characteristics. In other words, it may be difficult for a trade policy to become coherent and consistent in the face of an ever-demanding Congress, which represents variegated voices of widely-spread constituencies. Moreover, the Congress holds the "Commerce Power," ${ }^{29}$ which is a constitutional authority to regulate not only federal commerce but also foreign trade. This congressional mandate in foreign trade, together with the decentralized government structure, effectively dwarfs the president's power to formulate and implement trade policy in a coherent way, i.e., in a way that represents and values benefits to the broad national economy over narrow special interests. Thus, U.S. trade policy is vulnerable to capture and parochialism. It tends to be adrift at the mercy of sector-specific lobbies or in the vicissitudes of local economies whose constituencies are represented by Senators and Representatives in the House. ${ }^{30}$

Yet, another layer of decentralization within Congress further brews protectionist trade politics. In particular, the proliferation of subcommittees in Congress, especially in the post-Watergate era, provides fertile ground for protectionism. ${ }^{31}$ These subcommittees function as small kingdoms, often uninfluenced by and independent of party rules. Commanding relevant expertise and human capital in their particular jurisdictions, they

executive," "transparency of policymaking," "legalism in policymaking," "federalism," and "an insular popular culture." Id., at 32-53. Raymond Vernon, Debra Spar, and Glenn Tobin also regarded decentralization as a defining attitude of the US foreign trade policy. RAYMOND VERNON ET AL., IRON Triangles And ReVOlving DoOrs: CASES IN U.S. Foreign ECONOMIC POlicymaKing 4 (1991).

${ }^{28}$ AnNe O. Krueger, American Trade Policy: A Tragedy IN THE Making 2 (1995)

${ }^{29}$ U.S. CONST. art. I, §8.

${ }^{30}$ Stephen D. COHEN ET Al., Fundamentals of US Foreign Trade Policy: ECONOMics, POLITICS, LAWS AND ISSUES 115 (1996).

${ }^{31}$ Both chambers of the Congress together had more than 250 committees and subcommittees by the Nineties. PAARlBERG, supra note _, at 23. 
often incubate certain policies and control the agenda-setting. ${ }^{32}$ Empowered by this "gatekeeping" capacity, subcommittees facilitate the infamous processes of logrolling and porkbarrel spending. ${ }^{33}$ Consequently, members of Congress tend to divert a great deal of time and resources to parochial matters, which are of significant concern to their own constituencies, away from national law-making projects. ${ }^{34}$ On top of this, the U.S. bicameral system and the existence of a conference committee to reconcile the different versions of both chambers ("messaging between the chambers") also tend to reinforce the power and voices of committees since conferees are drawn mainly from committees of pertinent jurisdictions and represent the views of those committees with stakes in the deliberation process. ${ }^{35}$ It is not difficult to conclude that this decentralized subcommittee system attracts targeted lobbies from special interest groups. ${ }^{36}$

Of course, Congress has "delegated" its constitutional authority on foreign trade to the president. For example, in the Reciprocal Trade Agreements Act of 1934 Congress voluntarily delegated its power over trade policy to the executive after the disaster caused by the protectionist Smoot-Hawley Tariffs Act of 1930--deepening the Great Depression. ${ }^{37}$ Yet, as I. M. Destler aptly observed, such delegation is motivated by selfserving interests of legislators who wanted to insulate, and thus protect, themselves from

\footnotetext{
${ }^{32}$ ROWLEY ET AL., supra note _, at 113-16.

${ }^{33} \mathrm{Id}$., at 114.

${ }^{34}$ For example, more than a half of staff resources for members of the Congress is channeled toward local matters, rather than national law-making. Id.

${ }^{35} \mathrm{Id}$., at $117-18$.

${ }^{36} \mathrm{Id}$., at 122. See also M.P. FIORINA, CONGRESS: KEYSTONE OF THE WASHINGTON ESTABLISHMENT 122 (1988).

${ }^{37}$ Sharyn O'Halloran, Politics, Process, and American Trade Policy 71 (1994).
} 
lobbyists and local industries, rather than by a philosophical shift to liberal trade. ${ }^{38}$ Therefore, Congress still reserves its veto power in trade matters. ${ }^{39}$ The "fast track" authority is a case in point. Under the Trade Act of 1974, the Congress conferred the president a special authority, coined as "fast track" authority. Under this procedure, unlike usual legislative procedures, Congress up or down vote on trade agreements that the president has negotiated without any possibility of bottling up or adding amendments on the floor. Yet, this special entrustment in trade policy-making came with certain restrictions: Congress can still revoke fast track authority if Congress (certain committees or both houses) passes a resolution disapproving the president's authority. ${ }^{40}$ As a result, the executive should not only report to and consult with various congressional committees but also "enfranchise" special interests into the negotiation through hearings. ${ }^{41}$ Also, the president should accommodate special interests in the final trade agreement to ensure its passage even under the fast track authority. ${ }^{42}$

Although the executive often attempts to adopt and implement anti-parochial trade policies, often through international trade agreements, those attempts have been impeded and have even backfired due to an overzealous Congress that reclaimed its authority on the regulation of foreign trade. For example, by the mid-Eighties Congress had effectively undermined implementation of any U.S. trade agreement outcomes by

\footnotetext{
${ }^{38}$ See I.M. Destler, American TRAde POlitics: SYsTem Under StRESS (1986)

${ }^{39}$ O'HAlloran, supra note _, at 7. See also COHEN ET AL., supra note _, at 117 (1996) (observing that such delegation is limited in scope and duration); PATRICK LOW, TRADING FREE: THE GATT AND U.S. TRADE POLICY 130-32 (1993) (observing that such delegation is "with reserve" and "both incomplete and short term").

${ }^{40}$ O'HALlORAN, supra note _, at 141.

${ }^{41} \mathrm{Id}$., at 182.

${ }^{42} \mathrm{Id}$.
} 
utilizing trade remedies. ${ }^{43}$ For example, even if foreign market access to the U.S. market was improved through international deals, such improved access could be effectively curtailed by domestic measures such as antidumping measures.

Nonetheless, the president does not always command a broader (national) constituency than the Congress. ${ }^{44}$ Due to yet another aspect of the U.S. decentralized political system, the "electoral college," the president is often forced to exercise protectionism in a strategic way. ${ }^{45}$ The president may increase his or her chances of reelection by favoring certain industries whose economic interests are embedded in certain states that are either his or her traditional political stronghold or potential supporters such as swing states. This consideration may explain the political motivations behind President George W. Bush's "Steel Initiative" in 2001, which protected steel industries many of which are located in swing states such as Ohio and Pennsylvania, and "Farm Bill" in 2002, which protected southern farmers many of which are in President Bush's old political base, such as Texas.

Summing up, the underlying decentralized structure in the U.S. constitutional setting tends to make the U.S. trade policy inductive to special interests and local control. This unique political structure often forces U.S. trade policy to succumb to protectionism.

\footnotetext{
${ }^{43}$ See J. Michael Finger, The Origins and Evolution of Antidumping Regulation, WORLD BANK WORKING PAPERS (WPS 783), Oct. 1991, at 26-27.

${ }^{44}$ ROWLEY ET AL., supra note _, at 128-29; O'HALlORAN, supra note _, at 5.

${ }^{45} \mathrm{Id}$., at 129.
} 


\section{Lobbying}

In the U.S., lobbying is an important part of political life. Everyone can freely appeal to the government and politicians to speak up for his or her own (or others') interest. ${ }^{46}$ The constitutional optimism on the pluralist political process is embedded in the First Amendment ${ }^{47}$ and its jurisprudence such as the "marketplace of ideas." In his seminal dissenting opinion in Abrams v. U.S. (1919), Justice Oliver Wendell Holmes, joined by Justice Louis Brandeis, wrote that the "ultimate good desired is better reached by free trade in ideas." ${ }^{48}$ Robert Dahl also applied this "market" analogy to the political process by contending that political decisions are channeled by bargaining among interest groups and lawmakers in an aggregated form. ${ }^{49}$ Some even attempt to justify a "constitutional" right to lobby via constitutional theories or doctrines such as the right of petition theory and the associational privacy. ${ }^{50}$

Economists have demonstrated a causal relationship between lobbying and congressional votes. Timothy McKeown and Benjamin Fordham have concluded that economic interests, both as contributors and constituents, shape congressional floor votes as to trade policy. ${ }^{51}$ Critically, the cost of such lobby may not necessarily be high. In a

\footnotetext{
${ }^{46}$ See e.g., U.S. Senate, Lobbying Forms and Electronic Filing Center, available at http://www.senate.gov/legislative/common/generic/lobbying_registration.htm (last visited on Aug. 8, 2006).

${ }^{47}$ COHEN ET AL., supra note _, at 117.

${ }^{48}$ Abrams v. U.S., 250 U.S. 616 (1919).

${ }^{49}$ Chantal Thomas, Challenges for Democracy and Trade: The Case of the United States, 41 HARV. J.ON Legis. 1, 3 n. 12 (2004); RoberT DAHL, A PrefaCe TO DeMOCRATIC THeOry (1956).

${ }^{50}$ See Andrew P. Thomas, Easing the Pressure on Pressure Groups: Toward a Constitutional Right to Lobby, 16 HARV. J.L. \& PUB. POL'Y 149, 192-93 (1993).

${ }^{51}$ Timothy J. McKeown \& Benjamin O. Fordham, Selection and Influence, Interest Groups, and Congressional Voting on Trade Policy 28 (2000) (conference paper). Cf. Robert E. Baldwin \& Christopher
} 
provoking study, José Anson has showed that the U.S. steel lobby has spent a relatively small amount of money on campaign contributions for its protection in stark contrast with conventional wisdom. ${ }^{52}$ Likewise, Robert Fischer et al. also proved that votes for domestic steel protection could be bought cheaply in their study on the steel import quota bill of $1999 .{ }^{53}$ This counter-intuitively high return of the steel lobby may be expounded by its long history of lobby in the same sector as well as local politicians who are susceptible to lobbyists' influence..$^{54}$

As a result of this lobbying culture, the U.S. has a "producer-oriented, complainant-initiated trade policy system," ${ }^{55}$ which relatively ignores unorganized yet widely-diffused consumers' interest as well as the larger impact of domestic protection on the U.S. economy in general. As Anne Krueger aptly observed, "[I]f citizens could easily identify and directly vote on the magnitudes of gains and losses from protection," the current U.S. trade policies would be shifted..$^{56}$ She concluded that "American trade policy has become increasingly schizophrenic as fear of competition and pressures from special

Magee, Is Trade Policy for Sale?: Congressional Voting on Recent Trade Bills, 105 PuBlic CHOICE 79 (2000) (showing that campaign contributions influenced congressional votes on trade bills such as NAFTA and UR bills).

52 José Anson, Steel Trade Policy Lobbying at U.S. Congress: How Much Does Money Matter? (2003), available at http://www.hec.unil.ch/janson/steeldoc.pdf, at 12-13 (last visited on Aug. 12, 2005).

${ }^{53}$ Robert C. Fisher et al., Steeling House Votes at Low Prices for the Steel Import Quota Bill of 1999, DUKE ECON. WORKING PAPER \#02-24 (2002), at 19, available at http://www.econ.duke.edu/Papers/Abstracts02/abstract.02.24.html (last visited on Aug. 12, 2005).

${ }^{54}$ See e.g., U.S. Rep. Phil English, Steel Caucus, Others Lobby Administration Lobby for Maximum Help for Steel Industry, available at http://www.house.gov/english/press2002/bush201022202.html (last visited on Aug. 12, 2005). See also Steel's Tariff Addiction, Wall St. J, Aug.20, 2002.

${ }^{55}$ C. FRED BERGSTEN \& MARCUS NOLAND, RECONCILABLE DIFFERENCES?: UNITED STATES JAPAN ECONOMIC CONFLICT 191 (1993).

${ }^{56}$ KRUEGER, supra note _, at 3. 
interests influence a variety of sectoral policies even as we continue to assert our support for an open multilateral system." 57

Legalization of trade politic is an indispensable component in establishing the lobbying culture. Most U.S. trade statutes are designed for private industries to petition their own grievances to the government for any remedial measures. This structure is compatible with the American culture and values embodied in the First Amendment and the model of accountable, and thus democratic, government. In a sense, every industry which is allegedly harmed by unfair foreign trade practices acts like its own "private USTR.” Private industries in competition with foreign rivals control a unilateral enforcement mechanism by initiating such a process and also by providing the government with crucial information necessary for its investigation. ${ }^{58}$ This privatization of trade remedies under various statutes testifies to the "American obsession with regulation through formalized rules." 59

A litigious culture together with a vast army of lawyers in the U.S. (more than 700,000 as of the early Nineties) also tends to encourage special interests and their

${ }^{57} \mathrm{Id}$., at 6.

${ }^{58}$ David Palmeter, Commentary, in Aggressive Unilateralism: AmericA's 301 Trade POlicy AND THE WORLD TRADING SYSTEM 160 (Jagdish Bhagwati \& Hugh T. Patrick eds., 1990) [hereinafter Aggressive UnIlateralism];See also Jay L. Eizenstat, The Impact of the World Trade Organization on Unilateral United States Trade Sanctions Under Section 301 of the Trade Act of 1974: A Case Study of the Japanese Auto Dispute and the Fuji-Kodak Dispute, 11 EMORY INT'L L. REV. 137, 154 (1997); JOHN H. JACKSON, RESTRUCTURING THE GATT SYSTEM 70 (1990).

${ }^{59}$ J. Michael Finger, The Meaning of "Unfair" in United States Import Policy, 1 MinN. J. GLOBAL TRADE 35, 41 (1992). See also DESTLER, supra note _, at (documenting how changes in some details of the U.S. trade remedy law (antidumping statute), such as stricter deadlines and jurisdictional shift, caused a "flood" of petitions from domestic producers who could potentially benefit from those petitions). 
lobbyists to file lawsuits as a vehicle for their cases to be heard. ${ }^{60}$ Nearly three-quarters of all Washington lobbyists are reportedly involved in such litigation. ${ }^{61}$ While such extensive litigation may contribute to democratic virtues by ensuring public participation in the trade policy-making process, it may also block the formation of such trade policy that speak to the broader public interests. ${ }^{62}$

In summation, one might reasonably speculate that the ethos of "freedom" or "right" to stage and vindicate individual or sectoral interests, whose root may be found in the First Amendment, allows well-organized local industries to prevail over a rather vaguely-defined general interest of state or national economy. Certainly, Congress has been an effective conduit for such special interests. ${ }^{63}$ And, most importantly, the cost of lobbying is not high.

\section{B. The Context Transformed}

\section{The Diminishing Giant Syndrome}

While the celebrated and glorified fall of the Berlin Wall and the demise of the Cold War brought the U.S. a satisfying sentiment of triumph, this new international landscape also contributed to protectionist U.S. trade policies. In a uni-polar world, or

${ }^{60}$ PAARLBERG, supra note _, at 45.

${ }^{61}$ KAREN O'CONNOR \& LARRY J. SABATO, AMERICAN GOVERNMENT: ROOTS AND REFORM 551 (1994)

${ }^{62}$ PAARlBerg, supra note _, at 45.

${ }^{63}$ See The Lobbyist Empowerment Act, N. Y. TIMES, Apr. 26, 2006. 
Pax Americana, where the "Evil Empire" no longer exists, the U.S. feels less obliged to exercise its hitherto leadership for a free world and focuses much more on its narrow interests. Trade is no longer an issue of foreign policy, but of domestic policy subject to enormous pressures from interest groups. ${ }^{64}$ Notably, a renowned economist Jagdish Bhagwati dubbed this post-hegemonic phenomenon as the "Diminishing Giant Syndrome." ${ }^{65}$

During the Cold War, the U.S. could frame its national interest into a global, more precisely Western, interest. Senator Russell Long (D-LA), Chairman of the Finance Committee from 1965 to 1981, is said to have often criticized the State Department for sacrificing U.S. industrial interests to diplomatic considerations. ${ }^{66}$ Yet, in a post-Cold War era the U.S. has found fewer incentives to maintain such a long-term goal in foreign affairs. Likewise, the U.S. has also lost its tolerance for international organizations and has become more allergic to "international federalism." ${ }^{67}$ This weakened leadership and reduced commitment to multilateralism have provided a fertile ground for nurturing unilateral trade justice in the name of "fair trade. ${ }^{18}$ Senator Lloyd Bentsen, Senator Long's successor as Chairman of the Finance Committee, which drafted the Omnibus

${ }^{64}$ See Vinod K. Aggarwal, The Political Economy of Service Sector Negotiations in the Uruguay Round, 16 THE FLETCHER FORUM OF WORLD AFF. 35, 37 (1992) (viewing that "hegemonic decline" provide domestic political actors with "greater opportunities to press their cause and potentially disrupt international negotiations").

${ }^{65}$ Jagdish Bhagwati \& Douglas A. Irwin, The Return of the Reciprocitarians: US Trade Policy Today, 10 WORLD ECON. 109, 109 (1987).

${ }^{66}$ Paula Stern, Reaping the Wind and Sowing the Whirlwind: Section 301 as a Metaphor for Congressional Assertiveness in U.S. Trade Policy, 12.8 B.U. INT'L L.J. 1, 4 (1990).

${ }^{67} \mathrm{John}$ O. McGinnis, The Decline of the Western Nation State and the Rise of the Regime of International Federalism, 18 CARDOZO L. REV. 903, 903-04 (1996).

${ }^{68}$ ThOMAS O. BAyARD \& KimBERLY ANN ElLIOT, RECIPROCITY AND RETALIATION IN THE U.S. TRADE POLICY 4 (1994). 
Trade and Competitiveness Act of 1988 Act, once stated that "[T]here was a time when we were so dominant from an economic, political and military standpoint that we could afford to [concede those trade] points for some foreign policy objective of the moment. That day has passed. ${ }^{69}$

In summation, in the Cold War era, the U.S. acted as a hegemon by "[trading] short-term concessions for possible long-run gains." ${ }^{70}$ This is not the case any more. In the post-hegemonic era, U.S trade policy seems vulnerable to protectionist politics without strong foreign policy considerations.

\section{Bad Economy}

Recently, the widening U.S. trade deficit has alarmed both the public and the government and sparked a call for the rethinking of U.S. trade policy. ${ }^{71}$ Yet, it is one of the basics of national accounting that the trade deficit is a different name for the fiscal deficit. A nation's net imports, imports minus exports, mirror its net investment, investment minus saving. ${ }^{72}$ Therefore, nations should tighten its fiscal budget to narrow the trade deficit. However, it is doubtful, at least in the near future, whether the U.S.

\footnotetext{
${ }^{69}$ Stern, supra note _, at 7; 134 Cong. Rec. S4,657 (1988) (statement of Sen. Bentsen).

${ }^{70}$ Robert E. Baldwin, Changes in the Global Trading System: A Response to Shifts in National Economic Power, in PROTECTIONISM AND WORLd Welfare 83 [hereinafter Protectionism] (Dominick Salvatore ed. 1993).

${ }^{71}$ See W. Max Corden, The Revival of Protectionism in Developed Countries, in PROTECTIONISM, supra (observing that recessions or economic downturns tend to provide a fertile ground for protectionism).

${ }^{72}$ See generally PAUl R. KRUGMAN \& MAURICE OBSTFELD, INTERNATIONAL ECONOMICS: THEORY AND PRACTICE ch. 12 (National Income Accounting and the Balance of Payments) (5 ${ }^{\text {th }}$ ed. 2000); Harbingers of Harder Times, N.Y. TIMES, Mar. 12, 2005; Bob Herbert, The Era of Exploitation, N.Y. TIMES, Mar. 25, 2005.
} 
government will be able to tighten its fiscal belt with the recent sizable tax cut and everincreasing spending in the area of national security and defense, not to mention to increasing costs due to an ageing population. ${ }^{73}$ This unpleasant economic atmosphere is yet another fertile ground for protectionism and hostile reactions to foreign trade practices. Political pressures from domestic industries and labor unions become more intense as U.S. economic woes worsen. It often appears much easier for politicians to find fault with foreigners, their products and particular aspects of their production process, rather than admitting problems of U.S. domestic policies and attempting to fix them, especially when the federal budget is not adequate to cushion the impact of international trade via the social safety nets. ${ }^{74}$

In the late Eighties and early Nineties, when the U.S. suffered the same economic trouble, i.e., the Twin Deficit, the U.S. flexed its muscle and wielded its heavy weapon of unilateral trade policies such as Super 301 against those trading partners that held big trade surpluses vis-à-vis the U.S., such as Japan, Korea, and India. Under the threat of such trade sanction, numerous protectionist pacts such as Voluntary Export Restraints (VERs) were signed outside the legal realm of General Agreement on Tariffs and Trade (GATT). ${ }^{75}$ The notorious "Japan-bashing" was also salient on Capitol Hill. ${ }^{76}$ In a

\footnotetext{
${ }^{73}$ See Nicholas D. Kristof, The Greediest Generation, N.Y. TIMES, May 1, 2005.

${ }^{74}$ See Paul Krugman, Deficits and Deceit, N.Y. TIMES, Mar. 4, 2005;

${ }^{75}$ Under the WTO system, VERs are explicitly prohibited. See Agreement on Safeguards, Annex 1 A of the WTO Agreement, supra note _, art. 11 (Prohibition and Elimination of Certain Measures) ("a Member shall not seek, take or maintain any voluntary export restraints, orderly marketing arrangements or any other similar measures on the export or the import side.") (emphasis added). Regarding an economic analysis of various VERs, see Harry G. Hutchison, Distributional Consequences, Policy Implications of Voluntary Export Restraints on Textiles and Apparel, Steel, and Automobiles, 38 WAYNE L. REV. 1757 (1992) (arguing that VERs create inefficiency and reduce welfare).
} 
historical déjà vu, "China-bashing" has recently gathered steam in Congress. The U.S.'

mounting bilateral trade deficit with China has recently stimulated protectionist sentiments among politicians. ${ }^{77}$ Along the same lines, the U.S. government has recently pressured China to restrict its clothing and textiles exports to the U.S. ${ }^{78}$ China responded to this pressure by taxing their own exports, which seems to be inconsistent with the WTO rules. ${ }^{79}$ Yet, apparently unsatisfied with such export taxes, the U.S. government, despite the Chinese protest, has also pushed forward the idea of safeguard measures against Chinese textiles exports under a side deal, which China had to tolerate to become a WTO Member. ${ }^{80}$ Furthermore, in a move reminiscent of the Plaza Agreement in the Eighties, the U.S. government has demanded China to float its currency, renminbi, in hopes of improving the U.S. trade balance vis-à-vis China, which seems to be a futile policy according to experts. ${ }^{81}$

In summation, U.S. protectionist politics become intense in times of economic downturns, which tend to make the protectionist cycle coincide with the economic cycle.

\section{Social Psychology}

${ }^{76}$ See BAYARD \& ElLIOT, supra note _, at 32-49.

${ }^{77}$ Putting Up the Barricades, THE ECONOMIST, Apr. 25, 2005.

${ }^{78}$ Elizabeth Becker, U.S. Moves to Limit Imports from China, N. Y. TIMES, May 14, 2005.

${ }^{79}$ China Raises Export Duties on Textiles, 22 INT'L TRADE REP. No. 21, at 840-41 (2005); General Agreement on Tariffs and Trade, October 30, 1947, T.I.A.S. No. 1700, 55 U.N.T.S. 187, art. XI:1.

${ }^{80}$ United States Initiates Apparel Import Restrictions, Requests Talks with China, 22 INT'L TRADE REP. No. 21, at 841 (2005).

${ }^{81}$ Federal Reserve Board Chairman Alan Greenspan states that even 20\% appreciation of renminbi would not render any effect to the U.S. trade balance. Richard McGregor, Revaluing Renminbi 'Would Not Help U.S.,' FIN. TIMES, Feb. 6, 2005, at 4. 


\section{Asymmetrical Perception of Gains and Pains of Trade}

Benefits of trade, such as the increase of consumers' welfare and general growth effect, tend to materialize in the long-term. Those gains are also thinly-spread to many unidentified people who fail to appreciate them and take them for granted. However, the pains of trade, such as dislocation and adjustment, transpire quickly and become concentrated on particular groups of people, such as particular industries losing competitiveness and their workers, who are thus well-organized. Therefore, there exists an asymmetry in people's perception of benefits and costs of trade liberalization. ${ }^{82}$ This cognitive factor tends to reinforce a protectionist proclivity in trade politics because it is usually those well-organized interest groups that regularly patronize and thus capture politicians. It is difficult to build a free trade coalition comprised of consumers or the general public because, although benefiting from trade liberalization, they lack sufficient incentives to organize and lobby for free trade.

This cognitive asymmetry is further buttressed by the public choice theory. According to the theory, most voters tend to become ignorant of any particular trade policy because their interests are not affected directly and promptly on an individual basis. ${ }^{83}$ They lack incentives to study and inspect the benefits and costs of trade policies. Therefore, while these voters constitute the "malleable" median-voters and thus are critical in passing certain legislative acts, they are easily taken advantage of by well-

\footnotetext{
${ }^{82}$ See Sungjoon Cho, Doha's Development, 25 BERKELEY J. INT'L L. (forthcoming 2007).

${ }^{83}$ ROWLEY ET AL., supra note _, at 152.
} 
organized interest groups. ${ }^{84}$ Similarly, these neutral, median voters tend to show a "status quo bias" by being risk averse to any social disruption, such as dislocation, which may result from the elimination of trade protection. ${ }^{85}$ Therefore, the general population is inclined to support, or at least acquiesce to, pre-existing protectionist policies, rather than bear the feared negative consequences, such as social disturbance, of free trade policies.

\section{The Fear Factor}

As discussed above, perceptions or images of the effects of trade policies are created, imprinted and stored through a mechanism of human psychology that is prone to errors and irrationality. The graphic nature of local protests and violence waged against free trade creates fear in the minds of observers as to the consequences of foreign competition. This phenomenon of "social cascades" ${ }^{86}$ may leave very little room on people's cognitive radar for accepting the amorphous benefits of free trade, thereby disenabling them to evaluate free trade in an unbiased way. Therefore, while people may understand a general rationale of free trade in their mind, they are disinclined to accept some of its consequences in their heart. ${ }^{87}$

The nature of the news media is likely to reinforce the fear factor in the general population's evaluation of the consequences of free trade. News agencies tend to amplify

${ }^{84} \mathrm{Id}$, at 121

${ }^{85}$ See Douglas A. IRWin, Free Trade Under Fire 142 (2002).

${ }^{86}$ See generally CASS SUNSTEIN, RISK AND REASON (2002).

${ }^{87}$ See Sungjoon Cho, Vox Populi: People's Images on the WTO and Its Legitimacy, unpublished manuscript presented in the 2004 Annual Meeting of the Law and Society Association (Chicago, May 31, 2004) (on file with author); Daniel Drezner, Trade Talk, 1 AM. INTEREST 68, 70-71 (2005). 
the fear since their coverage mostly prioritizes rather flamboyant scenes, such as mass demonstrations and violence, which enjoy certain "news value." News agencies seldom air how free trade benefits the general public and the national economy as a whole, which may risk boring their audiences.

Yet, the problem is that the fear factor bestows on the vested interests good opportunities for controlling and even manipulating public images on free trade. A coalition of interest groups and politicians defend and advocate their protectionist positions by waging negative social marketing. They sensitize and often exaggerate negative side effects and other collateral damage from trade liberalization. For example, in the 1980's certain U.S. industries such as steel and automobiles, which were losing competitiveness vis-à-vis foreign countries, campaigned for protection as they took advantage of the fear of "deindustrialization" which conjured up "images of Americans reduced to flipping hamburgers at McDonald's" while those foreigners took over the main U.S. industries. ${ }^{88}$ Often, this fear-mongering is wedded to the catchphrases of national interests or patriotism. Domestic industries often attempt to justify protectionist measures by claiming that buying American serves the national interests of the U.S. and thus is patriotic. ${ }^{89}$

${ }^{88}$ Jagdish Bhagwati, Overview, in AgGRESSIVE UnILATERAliSM, supra note _, at 10.

${ }^{89}$ Todd E. Pettys, Our Anticompetitive Patriotism, 39 U.C. DAVIS L. REv. 1353, 1411-12 (2006) (quoting Thorstein Veblen who viewed that an "us-versus-them patriotism" are often introduced by those who are to gain from "such restraint of international trade as would not be tolerated within the national domain"). 
In sum, special interests tend to mobilize necessary political capital for

protectionist measures by means of a psychological warfare which takes advantage of people's fear of negative consequences of trade liberalization. This fear-mongering eventually rationalizes old and new protectionist policies.

\section{Revealing Pathologies of Protectionist Politics: A Dual Crisis}

\section{A. Domestic Crisis: Constitutional Failure}

Protectionism leads eventually to "constitutional failure" $" 90$ in that it goes against the foundations of the U.S. Constitution. It undermines the integrity of a federal marketplace by proliferating the rent-seeking behavior of special interests. (Madisonian failure) Protectionism also restricts trade, and thus competition, as domestic prices fail to fall due to such trade restrictions. Trade restriction can be translated into a deprivation of economic freedom reserved to market participants because it disables those market participants from engaging in certain economic transactions with foreign economic players that would guarantee greater efficiency and larger economic welfare than closed, domestic transactions. (Lockeian failure)

${ }^{90}$ Robert E. Hudec, Essays on the NATURe of International Trade LAW 133 (1999). See generally JAN TUMLIR, PROTECTIONISM: TRADE POLICY IN DEMOCRATIC SOCIETIES (1985). 
First, protectionism may be translated into a Madisonian failure in that national economic welfare is hijacked by a handful of domestic industries, which might be depicted as economic "factions." ${ }^{91}$ Trade protection, such as tariffs and quotas, is a form of "protection tax" which the public unsuspectingly pays in feeding those special interests. American consumers pay such protectionist tax equivalent to $17.2 \%$ when purchasing clothes due to trade barriers, $13.4 \%$ for leather luggage and $7.3 \%$ for footwear. ${ }^{92}$ All in all, American consumers pay an extra 6-7\% on protection taxes on average for imported staple goods. ${ }^{93}$ Protectionism also sacrifices jobs of the many to protect those of the few. For example, to save one job in the U.S. shrimp production sector, twenty other jobs in shrimp-consuming industries such as processing and distribution are sacrificed. ${ }^{94}$ Likewise, each steel job saved by U.S. antidumping tariffs cost three jobs in steel-consuming industries. ${ }^{95}$

Protectionism also entails antitrust behaviors of those rent seekers (special interests). For example, antidumping remedies tend to "cartelize" domestic markets because such measures restrict foreign producers' market entries and effectively fix prices by disallowing prices to fall. More often than not, the mere threat of antidumping

${ }^{91}$ See N. David Palmeter, The Capture of the Antidumping Law, 14 YALE J. INT'L L. 182, 190 n.44 (1989); Inge Nora Neufeld, Antidumping and Countervailing Procedures - Use or Abuse?: Implications for Developing Countries iii, Policy Issues in International Trade and Commodities Study Series No. 9, UNCTAD/ITCD/TAB/10 (2001).

${ }^{92}$ Consumers for World Trade, Protectionism in America: Watch Your Wallet, Nov. 1, 2003, at 2, available at http://www.cwt.org/learn/CWT\%20Protection\%20Tax\%20Study.pdf (last visited on July 3, 2006).

${ }^{93} \mathrm{Id}$.

${ }^{94}$ Consuming Industries Trade Action Coalition (CITAC), Facts about the Shrimp Dumping Case, available at http://www.citac.info/shrimp/about/fact_sheet.htm (last visited Nov. 29, 2004).

${ }^{95}$ See N. Gregory Mankiw \& Philip L. Swagel, Antidumping: The Third Rail of Trade Policy, 84 FOREIGN AFF. 107, 113 (2005). 
petitions by domestic producers invokes cooperative behavior (collusion) from a foreign producer since responding to the petitions are themselves enormous burdens to foreign producers regardless of the final results of the antidumping investigation. ${ }^{96}$

Second, protectionism deprives citizens of the economic freedom to consume and of the rights to property. Protectionism, as a form of government interference with the free market principle, cannot but undermine economic players' rights to trade and consume by forcing them to engage in such transactions as are distorted by protectionist measures. Thus, protectionism might violate rights to property in a Lockeian sense since those unwanted economic choices due to protection usually lead to increased economic costs incurred by importers and consumers. ${ }^{97}$ For example, American consumers could have paid far less for their automobiles and built their property (wealth), but for steel tariffs that were imposed to protect the moribund U.S. steel industry. The overall value of each American's property was forced to decrease on account of additional economic costs (tariffs) whose sole purpose was to protect special interests.

In sum, protectionist politics runs contrary to the founding principles of the U.S. in that it tends to undermine peoples' economic freedom and sacrifice economic welfare of the many for the few.

\footnotetext{
${ }^{96}$ See notably Pierre F. De Ravel Esclapon, Non-Price Predation and the Improper Use of U.S. Unfair Trade Laws, 56 ANTITRUST L.J. 543, 549 (1987).

${ }^{97}$ ROWLEY ET AL., supra note _, at 322.
} 


\section{B. International Crisis: American Exceptionalism}

Protectionist politics not only serves parochial interests at the expense of broader public interests but also blatantly disrespects the opinions of mankind in that it goes against the letter and the spirit of global trading norms. As an economic superpower, the U.S. is expected to lead other trading nations in pursuing free trade policy. Yet, while the U.S. has vigorously used the global trading system to deter its trading partners from adopting protectionist policies, it has not hesitated to support its own industries when they are in trouble..$^{98}$ This double standard, which is an icon of "American Exceptionalism," ${ }^{\prime 99}$ incurs various costs to the U.S.

Foreign reactions to American Exceptionalism vary. Very often, a targeted country eventually falls to continuous U.S. pressure and signs an agreement acquiescing to the demands of the U.S. Sometimes, these agreements result in an involuntary form of collusion in the global dimension because they tend to reduce the supply of certain products against free market mechanism, as seen in the VERs. ${ }^{100}$ Trading partners also replicate the U.S. protectionism for a strategic reason. The recent proliferation of

\footnotetext{
${ }^{98}$ See Dan Sarooshi, Sovereignty, Economic Autonomy, the United States, and the International Trading System: Representations of a Relationship, 15 EUR. J. INT’L L. 651 (2004). See also Kevin K. Ho, Trading Rights and Wrongs: The 2002 Bush Steel Tariffs, 21 BERKELEY J. INT'L L. 825 (2003); James M. Cooper, Spirits in the Material World: A Post-Modern Approach to United States Trade Policy, 14 AM. U. INT'L L. REV. 957 (1999); Michael Hudson, SuPER IMPERIAlism: The ORIGINS AND Fundamentals of U.S. WORLd DOMINANCE 251 (2d ed. 2003).

${ }^{99}$ See Koh, supra note _, at 1483.

${ }^{100}$ See Ulrich Immenga, Export Cartels and Voluntary Export Restraints between Trade and Competition Policy, 4 PAC. RIM L. \& POL'Y J. 93, 132-33 (1995).
} 
antidumping remedies, especially among developing countries, is attributable largely to their defensive behaviors against the U.S. active use of this type of protectionism. ${ }^{101}$

Nonetheless, exceptionalism always carries serious costs. It incurs a certain "reputation cost" since these policies appear illegitimate to the eyes of foreign trading partners. ${ }^{102}$ The result may be a loss of "soft power," namely the ability to set the agenda and lead others to follow it. ${ }^{103}$ Yet more grave cost may come from the risks of retaliation

and subsequent trade war. ${ }^{104}$ Recently, ever-growing transatlantic trade tension as well as the rise of China's economic influence tends to make such risks more likely. It should be noted that any trade war may actually result in a collapse of the entire multilateral trading system and devastate economies of individual trading nations, including the U.S. As Professor Harold Koh warned, U.S. exceptionalism, if left unchecked, will eventually weaken the legitimacy and efficacy of global trading rules preventing the U.S. from relying on those rules when it needs them the most to pursue its own national interests. ${ }^{105}$

\section{Judicial Regulation of Protectionist Politics: A New Constitutional Dynamics}

${ }^{101}$ See Christopher F. Corr, Trade Protection in the New Millennium: The Ascendancy of Antidumping Measures, 18 NW. J. INT'L L. \& BUS. 49 (1997).

102 See Jared R. Silverman, Multilateral Resolution over Unilateral Retaliation: Adjudicating the Use of Section 301 before the WTO, 17 U. PA. J. INT'L ECON. L. 233, 286 (1996).

103 JOSEPH S. NYE JR., THE PARADOX OF AMERICAN POWER: WHY THE WORLD'S ONLY SUPERPOWER CAN'T GO IT ALONE 162 (2002).

${ }^{104}$ Silverman, supra note _, at 287.

${ }^{105}$ Koh, supra note _, at $\overline{1487 .}$ 


\section{A. A Case for a Judicial Approach}

As discussed above, a confluence of varying factors, such as the unique government structure of the U.S., changed circumstances and social psychology, is attributable to the recent rise of protectionism in the U.S. Although such trade politics may be explicable, it is not justifiable, its grave costs, not only to the U.S. but also to the rest of the world, warrant appropriate disciplines on the U.S. via apolitical, i.e., legal, means. Yet, such legalization should not be left exclusively to the Congress, which is subject to capture. A number of trade statutes are in fact the outcome of legalization of trade politics through logrolling and pork-barreling. ${ }^{106}$ Under these circumstances, legalization tends to exacerbate protectionist politics, rather than discipline it.

Therefore, another government branch, i.e., the Judiciary, should intervene under the constitutional principle of checks and balances. The court may review, from a due process perspective, the constitutionality of those trade statutes which lack an adequate level of deliberation as a result of protectionist trade politics. It also can require lawmakers to demonstrate a compelling reason to protect special interests at the expense of the larger public interest. The court can even internalize free trade norms under the WTO, such as non-discrimination, by invoking related constitutional principles such as Equal Protection and Charming Betsy. In sum, a constitutional, not simply legal, approach is in order to discipline protectionist trade politics.

\footnotetext{
${ }^{106}$ See notably E. E. Schattschneider, POLITICS, PrESSURES AND THE TARIFF: A STUDY OF FrEE Private ENTERPRISE IN PRESSURE POlitiCS, AS SHOWN IN THE 1929-1930 REVISION OF THE TARIFF (1935) (documenting the log-rolling phenomenon under the notorious Smoot-Hawley Tariffs Act of 1930).
} 


\section{B. Reinvigorating the Due Process}

The Judiciary may broaden the road to deliberation and thus contribute to more adequate representation of non-protectionist voices from the public. ${ }^{107}$ Professors Daniel Farber and Philip Frickey have located this opportunity in the court's more "aggressive overseeing" of the legislative process to check the power of special interests. ${ }^{108}$ The court may mandate legislative deliberation by cautiously establishing the "prima facie unconstitutionality" of certain suspect groups of legislation that can be cleared only by demonstrating the existence of such deliberation. ${ }^{109}$ Moreover, at a more technical level the court may focus on the "procedural regularity" that the Congress itself established. ${ }^{110}$ Farber and Frickey noted that according to the wisdom of public choice theorists, such strict compliance with procedural disciplines deters strategic behaviors by special interest groups. $^{111}$

By requiring this legislative deliberation, the court can effectively check certain abusive legislative behavior in the Congress, such as the "rider" or the "earmark." A rider means a certain provision sneakily attached ("earmarked"112) to an unrelated statute

\footnotetext{
${ }^{107}$ But see Larry D. Kramer, Putting the Politics Back into the Political Safeguards of Federalism, 100 COLUM. L. REV. 215, 219 (2000) (opposing "aggressive judicial interference in politics").

${ }^{108}$ Daniel A. Farber \& Philip P. Frickey, The Jurisprudence of Public Choice, 65 TEX. L. REV. 873, 914-20 (1987).

${ }^{109}$ Id., at 919-20.

${ }^{110} \mathrm{Id}$., at $920-24$.

${ }^{111} \mathrm{Id}$.

${ }^{112}$ See Jeff Flake, Earmarked Men, N.Y. TimEs, Feb. 9, 2006; Son of the Bridges to Nowhere, N.Y. TIMES, Apr. 23, 2006.
} 
because such provision cannot survive the congressional debate or vote on its own merits. ${ }^{113}$ The rider tends to "force passage" 114 by simply riding on an important piece of legislation, such as an appropriation (spending) bill. Because the Congress must adopt the bill only as a whole, the rider tends to guarantee its passage regardless of its merits. Therefore, some powerful politicians often introduce blatantly protectionist riders which cater only to particular constituencies.

Using the rider, Congress, which was captured by southern catfish farmers, passed a notorious statute prohibiting Vietnamese catfish farmers from marketing their products as "catfish" in the U.S. without any scientific grounds. ${ }^{115}$ Attached to an agricultural appropriation bill, this protectionist piece of legislation was passed "without debate and a vote." ${ }^{116}$ It was also through a rider that another notorious protectionist statute, the Byrd Amendment, ${ }^{117}$ was passed without any debate as it was attached to a 2001 spending bill. From 2001 to 2004, USD 1 billion collected as antidumping duties were distributed to U.S. domestic producers who filed antidumping complaints against foreign rivals. ${ }^{118}$ Surprisingly, two-thirds of such a large amount of money went to only three industries:

${ }^{113}$ Project Vote Smart, Government 101: How a Bill Becomes Law, at http://www.votesmart.org/resource govt101 02.php\# riders (last visited Aug. 15, 2004).

${ }^{114}$ Adam Smith, Partisan 'Riders' Hold Good Legislation (June 11, 1997), available at http://www.house.gov/apps/list/hearing/wa09_smith/970611op.html.

${ }^{115}$ See Sungjoon Cho, A Dual Catastrophe of Protectionism, 25 NW. J. INT'L L. \& BUS. 315, 319 (2005).

${ }^{116}$ Press Release, U.S. Senator John McCain (Arizona), Catfish Import Barrier Puts International Trade Agreements at Risk (Dec. 18, 2001), at http:// ccain.senate.gov/index.cfm?fuseaction $=$ Newscenter.ViewPressRelease $\&$ Content_id $=279$.

${ }^{117}$ U.S. Customs and Border Protection, The Continued Dumping and Subsidy Offset Act of 2000, available at http://www.cbp.gov/xp/cgov/import/add_cvd/cont_dump/ (last visited Aug. 9, 2006).

${ }^{118}$ The Byrd Lottery, CHI. TRIBUNE, Dec. 2, 2005. 
steel, candles, and ball bearings. ${ }^{119}$ In 2005, the Senate Agriculture Committee voted to extend agricultural subsidies expiring in the 2007 Farm Bill until 2011 by sneakily inserting these subsidies in a budget bill, rather than debating it as part of the Farm Bill. ${ }^{120}$

Requiring a legislative deliberation, such as adequate debates or a vote, can effectively check the abusive practice of riders by disclosing their protectionist nature in the public sphere.

In addition to this procedural, structural aspect of due process, the court should also bring into play "substantive" aspects of due process in tackling captured trade politics. The "substantive due process" under the Fifth and the Fourteenth Amendment subjects the government to strict scrutiny when it undermines, via its regulation or legislation, "fundamental" values of individuals, such as life, liberty, and property. ${ }^{121}$ For the purpose of this paper, one might construe the liberty as connoting "economic freedom" by which each and every economic player can freely compete in the market without undue government interferences. As discussed above, protectionism tends to violate economic liberty (or rights to property) of economic players, such as importers and consumers, by depriving them of economic opportunities of choosing foreign goods over like domestic products which have become more costly than the former due to protection. ${ }^{122}$

${ }^{119} \mathrm{Id}$.

${ }^{120}$ Cow Politics, N.Y. Times, Oct. 27, 2005.

${ }^{121}$ U.S. CONST. amend. V, XIV.

${ }^{122}$ However, the U.S. Court once viewed this economic liberty or right to property as a mere "privilege" to be limited by the government, rather than as a "right" per se. ROWLEY ET AL., supra note _, at 328. See also Buttfield v. Stranahan (1904) (ruling that "no one has a vested right to trade with foreign nations"). In this regard, Milton Friedman once argued for a "Free Trade Amendment" to the U.S. 
Admittedly, this proposition might be viewed as a departure from the current U.S. constitutional jurisprudence in that the titular "substantive economic due process" clause once symbolized by Lochner came to its demise a long time ago. In the pre-depression era, the Lochner court notoriously struck down a New York statute limiting bakers' working hours as a violation of economic liberty under the Fourteenth Amendment. ${ }^{123}$ Yet, as Justice Holmes lambasted with a metaphor of Social Darwinism in his dissent, ${ }^{124}$ Lochner was severely criticized as a blind pursuit of laissez-faire economic theory at the expense of legitimate social regulation, such as protection of the economically powerless. ${ }^{125}$ Lochner was eventually overruled by Parrish in which the Supreme Court upheld a state minimum wage law. ${ }^{126}$

Crucially, however, the end of the Lochner era should not be automatically translated into undue justification of protectionist government measures. While the Court should not employ the substantive due process doctrine to hinder the government from pursuing "legitimate," i.e., non-protectionist, policy objectives, as the Lochner court did in 1905 , at the same time it should not endorse protectionism via weak judicial review

Constitution to restrict the Congress' power to restrict foreign trade and guarantee people's rights to trade. M. Friedman \& R. Freidman, Free TO CHOOSE: A PeRsonAl STATEMENT 304 (1979).

${ }^{123}$ Lochner v. New York, 198 U.S. 45 (1905).

${ }^{124} \mathrm{Id}$., at 75-76.

${ }^{125}$ See Williamson v. Lee Optical of Oklahoma 348 U.S. 483 (1955) ("The day is gone when this Court uses the Due Process Clause of the Fourteenth Amendment to strike down state laws, regulatory of business and industrial conditions, because they may be unwise, improvident, or out of harmony with a particular school of thought."). Regarding the recent revival of this "particular school of thought" emphasizing economic liberties in the line of law and economics movement, see Jeffrey M. Shaman, On the $100^{\text {th }}$ Anniversary of Lochner v. New York, 72 TENN. L. REV. 455, 502-03 (2005); Note, Resurrecting Economic Rights: The Doctrine of Economic Due Process Reconsidered, 103 HARV. L. REV. 1363, 1363-64 (1990).

${ }^{126}$ West Coast Hotel Co. v. Parrish, 300 U.S. 379 (1937). 
in the mechanical compliance with post-Lochner rationality test. ${ }^{127}$ The government should be required to demonstrate that its measure is truly necessary to achieve the putative regulatory goals under strict scrutiny, instead of being immunized from any meaningful judicial investigation. ${ }^{128}$

In fact, a careful reading of Parish corroborates this position. The Parrish court emphasized an "additional and compelling consideration" which should be devoted to address the exploitation of workers in the depression era. ${ }^{129}$ The court took a "judicial notice of the unparalleled demands for relief" under the new circumstances. ${ }^{130}$

Accordingly, the Parish court upheld an economic regulation, i.e., a state minimum wage law, on the condition that such a regulation was necessary to achieve a legitimate policy objective, i.e., prevention of exploitation of workers.

Although Parish overruled Lochner in a formal, technical sense, these two jurisprudences could still be interpreter in a coherent fashion under the substantive due process doctrine. Tellingly, the substantive due process doctrine is not without restraints. Even under the doctrine the government can still restrict economic liberty, if it presents a compelling reason to regulate. Therefore, while Lochner offers the first part of substantive

${ }^{127}$ In other areas, such as Taking Power, one might witness a revival of long-dead substantive economic due process in the court's recent position requiring the "proportionality" between government actions and its goals, which is stricter than a conventional rationality test. See Abraham Bell \& Gideon Parchomovsky, Takings Reassessed, 87 VA. L. REV. 277, 286-87 (2001).

${ }^{128}$ Richard E. Levy, Escaping Lochner's Shadow: Toward A Coherent Jurisprudence of Economic Rights, 73 N.C. L. REV. 329, 422-24 (1995) (arguing for a "unified proportionality test," which is equivalent to the strict scrutiny, in the judicial review of economic regulations).

129300 U.S. 399 (1937).

${ }^{130} \mathrm{Id}$. 
due process doctrine, which represents an ideal of free market and free competition, Parrish highlights the second part of the doctrine, which denotes legitimate state intervention. In this sense, Lochner's legacy still echoes today. ${ }^{131}$ Lochner can be reincarnated as a judicial statement reaffirming the principle of market neutrality free from unwarranted government favoritism, which corresponds to the Madisonian antifactionism.

Therefore, the government should not infringe freedom from restraints on trade by protecting specific industries, unless it can demonstrate that such protection is legitimate and that its benefits to society overweighs any adverse impacts to the "constitutionally protected interests," such as those of consumers. ${ }^{132}$ This scrutiny inevitably invites a Madisonian test under which any possible benefits from favoritism (protection) are weighed and balanced against the broader public interest deriving from free competition (economic freedom). Trade protection would fail the test, except for certain extraordinary measures, such as safeguards under Section $201 .{ }^{133}$

In sum, the court's reinvigoration of the structural and substantive due process principle will effectively discipline the rent-seeking protectionism by rendering the political economy of international trade more transparent and thus revealing to the public a true national balance sheet of protectionism.

${ }^{131}$ See notably Cass R. Sunstein, Lochner's Legacy, 87 COLUM. L. REV. 873 (1987).

${ }^{132}$ Amartya Sen, the winner of Nobel Prize in economics, also observed that "a denial of opportunities of transaction, through arbitrary controls, can be a source of unfreedom in itself. People are then prevented from doing what can be taken to be - in the absence of compelling reasons to the contrary something that is within their right to do." AMARTYA Sen, DeVElopment AS FreEDOM 25 (1999).

${ }^{133}$ Section 201 of the Trade Act of 1974, 19U.S.C. 2251. 


\section{Internalizing Free Trade Principle}

The Framers found a powerful ideology of nation-building via a common market in the $18^{\text {th }}$ century international law scholar Emmerich de Vattel's vision of the Law of Nations and free trade cosmopolitanism. Vattel viewed that:

Nature rarely produces in one district all the various things men have need of; (...) If all these districts trade with one another, as nature intended, none of them will be without what is necessary and useful to them, and the intention of nature, the common mother of mankind, will be fulfilled. (...) Such is the foundation of the general obligation upon Nations to promote mutual commerce with one another. ${ }^{134}$

Premised on the notion that what should be among sovereign nations should also be among states, ${ }^{135}$ the Federalist Papers highlighted that the benefits of free, expanded interstate commerce not only address "reciprocal wants at home" but also contribute to "exportation to foreign markets," negative legacy that the Articles of Confederation had left, i.e., economic balkanization precipitated by tariff war among the Confederates was an eloquent testimony of this vision of free trade among states. ${ }^{137}$ Thus, the Constitution conferred upon the Congress a power to regulate international trade under the Commerce Clause. ${ }^{138}$

\footnotetext{
${ }^{134}$ Emmerich de VATtel, The LaW of NATIONS OR the Principles of NATURAl LaW ApPlied TO THE CONDUCT AND TO THE AFFAIRS OF NATIONS AND OF SOVEREIGNS 121 (1758) (Charles G. Fenwick trans., 1916).

${ }^{135}$ Douglas G. Smith, Interstate Commerce and the Principles of the Law of Nations, 2004 UTAH L. REV. 111, 129-30 (2004).

${ }^{136} \mathrm{Id}$., at 139.

${ }^{137} \mathrm{Id}$., at $131-32$

${ }^{138} \mathrm{Id}$., at 140
} 
This holistic understanding of internal (interstate) and external (foreign) trade under the U.S. Constitution, which can be translated into a constitutional commitment to openness, speaks for an internalization of international trade in the constitutional context. The government should self-discipline protectionist trade politics by heeding its long-term interest as to the rule of law in the sphere of international trade, which is of its own interest, not just of a utopian or cosmopolitan obligation totally detached from the genuine national interest. ${ }^{139}$ One may recall that it was not "selfless altruism," but "farsighted, enlightened self-interest," for the U.S. to reconstruct the international economic order through GATT after the World War. ${ }^{140}$ Although such a long-term interest, or value, is subject to a higher discount rate than a shorter-term and more immediate national interest, it is still the U.S. interest. In internalizing the long-term interest against narrow-minded special interests, the Judiciary is in a better position than other branches that are vulnerable to various means of capture.

In internalizing free trade principle, the Court can take full advantage of the doctrine of the "Dormant Commerce Clause." It is a sort of judicial innovation under which states are prohibited to enact a discriminatory statute to the detriment of foreign trade as well as interstate commerce. ${ }^{141}$ For example, in Goya De Puerto Rico Inc. v. Neftali

\footnotetext{
${ }^{139}$ See Jack Goldsmith, Liberal Democracy and Cosmopolitan Duty, 55 STAN. L. REV. 1667, 1668 (2003). The biggest problem in his analysis is that he excluded a "long-term" interest such as international peace and security from those of liberal democracies under the label of naively sounding "cosmopolitanism." Id. See also Daniel W. Drezner, On the Balance between International Law and Democratic Sovereignty, 2 CHI. J. INT'L L. 321, 336 (2001) (concluding that a recent surge of international law "violates" democratic sovereignty).

${ }^{140}$ See Paul Krugman, The Martial Plan, N.Y. TimES, at 27, Feb. 21, 2003.

${ }^{141}$ See Laurence H. Tribe, American Constitutional Law 1030 (3d ed., Vol. I., 2000). See also Dennis v. Higgins, 498 U.S. 439, 446 (1991).
} 
Santiago (1999), a U.S. court struck down a Puerto Rican regulation requiring exclusively foreign importers of pigeon peas to undergo an inspection and paying for the inspection fee. ${ }^{142}$ The court ruled that such regulation violated the Commerce Clause since the regulation "facially discriminate against interstate commerce" as it "imposes significant costs on pigeon pea importers which are not borne by their local counterparts. ${ }^{1143}$ The court also observed that Puerto Rico failed to demonstrate that the challenged regulation "serves a legitimate local interest," spotlighting that the Puerto Rico Department of Agriculture "could have adopted the same safety measures that it implements as to the locally grown pigeon peas. ${ }^{\prime 14}$ In this regard, the Dormant Commerce Clause can be a powerful legal instrument in striking down protectionist local measures.

As another possible means to internalize international norms, the Supreme Court developed, through yet another judicial ingenuity, a federal stronghold in the areas of foreign affair. Justice Wendell Holmes' celebrated holding in Holland is still reverberating, with an ever stronger force, against the background of the current global trading community "where the States individually are incompetent to act." ${ }^{145}$ Just as migratory birds in Holland, commerce itself is "transitory," knowing no state borders, whose nature defies any parochialistic restrictions. Commerce, while circulating through state and national borders, realizes a broader terrain of collective welfare, which is both national and inter-national, than a narrowly defined state interest. In sum, open trade is a federal

\footnotetext{
${ }^{142}$ Goya De Puerto Rico Inc. v. Neftali Santiago, 59 F. Supp. $2 d 274$ (1999).

${ }^{143} \mathrm{Id}$., at 277.

${ }^{144} \mathrm{Id}$., at 278 .

${ }^{145}$ State of Missouri v. Holland, 252 U.S. 416 (1920).
} 
matter since its obligation stems from international agreements. Therefore, trade value should prevail over parochial trade politics.

Finally, the Court can refer to international law, such as the WTO norms, as a normative anchor in disciplining protectionism, thereby connecting the domestic and international sphere under the fidelity to openness. The celebrated Charming Betsy doctrine stipulates that judges should interpret domestic statutes in a way which can avoid any possible conflicts with law of nations (international law). ${ }^{146}$ In the same vein, eminent constitutional law scholars, including the U.S. Supreme Court Justice Sandra Day O'Connor, have argued that domestic court decisions should be more coherent with foreign, international law (court decisions) regarding similar subject-matter. ${ }^{147}$

\footnotetext{
${ }^{146}$ Murray v. Schooner Charming Betsy, 6 US 64, 2 Cranch 64 (1804); See Ralph G. Steinhardt, The Role of International Law as a Canon of Domestic Statutory Construction, 43 VAND. L. REV. 1103, 1197 (1990).

${ }^{147}$ See e.g., Bradford R. Clark, Federal Common Law: A Structural Reinterpretation, 144 U. PA. L. REv. 1245, 1276 (1996) (arguing that the law applied by the Supreme Court in Swift v. Tyson (1842) was a "customary body of rules" derived from jus gentium and that no court is free to establish its own hermeneutics in departure from it). From a congruent standpoint, Justice O'Connor advocates that domestics courts should "faithfully recognize the obligations imposed by international law" as seen in Murray v. Charming Betsy and the Paquete Habana. See Sandra Day O'Connor, Federalism of Free Nations, 28 N.Y.U. J. INT'L L. \& POL. 35, 38-41 (1995-96). She emphasizes the federalist ideal of healthy dialogue and mutual trust which may be formed between domestic courts and transnational tribunals, which might be depicted in terms of Kant's "federalism of free nations." Id. See also Sandra Day O'Connor, Broadening Our Horizons: Why American Lawyers Must Learn About Foreign Law, 45-SEP FED. LAW. 20, 20-1 (1998) (highlighting the flexibility and dynamism of the common law tradition which enables the borrowing of new ideas form other legal systems and permits the "civilizing fiction of constitutional law"); Bruce Ackerman, The Rise of World Constitutionalism, 83 VA. L. REV. 771, 775 (1997) (advising his readers strongly to "look upon the American experience as a special case, not as the paradigmatic case"); Roger J. Miner, The Reception of Foreign Law in the U.S. Federal Courts, 43 AM. J. CoMP. L. 581, 581 (1995) (observing that the U.S. federal courts tend to "duck and run" in the face of foreign law issues despite that they are beginning to "form a significant part of the business of the federal courts"); Mark Tushnet, The Possibilities of Comparative Constitutional Law, 108 YALE L. J. 1225, 1228 (1999) (introducing a "more systematic approach to the possibility of learning from constitutional experience elsewhere"). Cf. W. Michael Reisman, Through or Despite Governments: Differentiated Responsibilities in Human Rights Program, 73 IOWA L. REV. 391, 394-97 (1987) (introducing Georges Scelle's celebrated argument for "dedoublement fonctionnel” which views domestic courts as "functional international courts").
} 
This judicial version of paying a "decent Respect to the Opinions of Mankind"148 may be conceptualized as "indirect recognition" of international norms by the domestic court. ${ }^{149}$ Under indirect recognition, while judges are not obliged to directly apply WTO norms to domestic cases, they may still harmonize their decisions with global trade norms by invoking certain domestic norms which mirror those global norms. For example, the Equal Protection Clause of the U.S. Constitution can be employed to proffer global trade rules, such as non-discrimination, in local courts to regulate trade politics. Protectionism is to favor narrow special interests at the expenses of the politically diffused, and thus weak, majority. Protectionism, while violating the National Treatment Clause under the WTO, may also be inconsistent with the Equal Protection Clause in that it discriminates between enterprises in like circumstances. Such indirect recognition ensures that domestic and international law communicate with, and finally constitutes, each other in a converging fashion. This judicial communication achieves a constitutional goal of taming trade politics.

\section{Conclusion}

Protectionism is an icon of trade politics, and it has been part of our political life ever since the creation of the nation. It is not only a reflection of the U.S. governance structure, such as decentralization, and the culture of lobbying, but also a reaction to

\footnotetext{
${ }^{148}$ THe DeClaration OF INDEPENDENCE, para. 1 (U.S. 1776).

${ }^{149}$ See Sungjoon Cho, The Nature of Remedies in International Trade Law, 65 U. PITT. L. REV. 763, 802-08 (2004).
} 
changing environments, such as the end of the Cold War and bad economy. Together with social psychology, such as cognitive asymmetry in perceiving gains and pains of trade as well as fear, the foregoing structural and contextual factors explain why protectionist politics prevails. Although protectionism may be explicable, it cannot be justifiable. Protectionism tends to incur unacceptable burdens, both internal (protectionist tax and cartelization) and external (American Exceptionalism), to the nation on the whole in exchange for narrow special interests.

If protectionism is a political pathology, it should be addressed by apolitical means, i.e., law. Yet, special interests' capture of rule-makers necessitates a broader, i.e., constitutional, approach in tackling trade politics. In this regard, the Judiciary can check and monitor the Congress to discipline protectionist politics through various constitutional instruments, such as due process and internalization of open trade principles. As a nation built upon universal values, such as freedom and nondiscrimination, the U.S. should civilize its trade politics through constitutional disciplines on economic discrimination, i.e., protectionism of us v. them. ${ }^{150}$

\footnotetext{
${ }^{150}$ See Pettys, supra note _, at 1405-06
} 